\title{
THE EFFECT OF JOB SATISFACTION, MOTIVATION AND ORGANIZATIONAL COMMITMENT TO THE PERFORMANCE OF THE PROCUREMENT EXPERTS IN THE INDONESIAN HOUSE OF REPRESETATIVE
}

\author{
Zahera Mega Utama \\ Mega.abta@gmail.com \\ Borobudur University
}

\begin{abstract}
The objective of this research has to study the effect of job satisfaction, motivation and organizational commitment on performance or the board of expert staff members of parliament, The research was conducted in Jakarta, and The data had been analyzed using path analysis. The population of this research were 91 person of expert staffs in the Parliament. The questionares of this research had been testing on the 40 expert staff. Therefore by simple randomly. The research finding more as follows : 1 . There was positive direct effect of job satisfaction onexpert staffs performance, 2, there was a positive direct effect of motivation on performance of expert staff 3. There was a positive direct effect of organization commitment of expert staff. 4. There was a positive direct effect of organization commitment on performance, 5. There was a positive direct effect of job satisfaction on motivation of expert staff and 6. There was a positive direct effect job satisfaction on organizational commitment
\end{abstract}

Keywords: Expert Staff Performance, Job Satisfaction, work motivation, Organizatinal commitment,

House of Representatives of the Republic of Indonesia (DPR RI) as the State supreme institution which accommodates and realizes people aspiration has a very strategic duties and functions, particularly in democratic improvement and development in Indonesia. One benchmark of democration development level in Indonesia can be seen to which extent the Indonesian House Representatives (DPR RI) has able to conduct its duty and function in accordance with the growing demand in society.

To conduct all of the duties and authorities, performance of a board member of the Indonesian House Representatives (DPR RI) is assisted by several member experts, Fraction Experts, board procurement experts, in conducting duty and discussion of various law drafts which will be discussed/drafted jointly with the government. It means that the interests of board members to an expert is the main substantial and functional needs besides it is governed by law, or in a simple language, to have expert member is a constitutional right that attaches to the function and title of legislators, either in the Indonesian House Representatives (DPR RI), Regional House of Representatives of Province and Regency/Municipality.

In the development of the Indonesian House Representatives (DPR RI) from time to time, there is demand of expertise support in conduction the constitutional duties. In the long journey of the Indonesian House Representatives (DPR RI), the presence of Expert (TA) was initially designed as procurement tool and fraction 1999. The demand is then developed to be the need of members of the Indonesian House Representatives (DPR RI) that is realized by providing expert member for members of the Indonesian House Representatives (DPR RI) since 2004. At the beginning, the need was only 1 (one) person and then later increased to be 2 (two) persons, during 2014 up to 2019 the need of expert member, fraction and procurement of board (AKD) were increasing in number of quota. For expert member was increased to 5 persons, fraction expert was in total of approximately 15 persons and board procurement expert (AKD) was in total of 10 persons in each Commission and Board. 
There are many factors able to affect the expert (TA) performance namely environment and individual factors. According to Barley et al., performance is affected by traits have by individual, effort, work and organizational support. ${ }^{1}$ Meanwhile Amstrong and Baron identify performance in four classification namely :

a. Personnal factors, include individual skill, competence, motivation and recruitment,

b. Qualified leadership factors, include motivation, coaching and encouragement,

c. Factor of work system and facility given by organization,

d. Situational factors include changes and pressure from internal and external factors.

The problem for performance of procurement experts of the Indonesian House Representatives (DPR $\mathrm{RI})$ is the absence of performance assessment or rule of discipline as made for Civil Servant, where there is performance assessment being evaluated annually and discipline in the form of condition to present in working hours on time. The expert (TA) performance has a very important role in the purpose achievement. The expert (TA) performance will be perceived by the relevant board member in conducting his/her daily duties and obligations in the legislative institution. Therefore, an expert (TA) performance is expected to be completely competent in his/her field and as expert (TA) performance must also be able to dedicate optimally and has maximum performance. An expert member must have minimum post graduate education and has minimum experience of 5 years working period in the House of Representative (DPR) institution.

This article discusses the performance issue of board procurement experts of the Indonesian House Representatives (DPR RI), which we know that performance has used as a measure of success of an office at all times. A success of a working individual or group may also be indicated from the performance. Thus, performance is a purpose to make success of an organization. Therefore, performance is defined as all profieciencies and behaviors which affect work outcomes in an office authority and work responsibility that is accountable in an organization. The stronger motivation of a person, his/her behavior is increasingly directed in achieving purpose. Organizational authority, in addition to direct behavior, also stimulates and strengthens motivation of organizational member so that he/she directed behavior and consistent the achievement of organizational objectives.

The Writer's research topic is the relation of performance and work satisfaction, work motivation, organizational commitment to performance of board procurement expert of the Indonesian House Representatives (DPR RI). From the identification above, the Writer made formulation of the issue will be discussed in this writing area: 1). Is there a direct effect of job satisfaction to performance? 2). Is there a direct effect of motivation to performance? 3). Is there a direct effect of organizational commitment to performance? 4). Is there direct effect of job satisfaction to performacne? 5). Is there a direct effect of motivation to commitment? 6). Is there a direct effect of job satisfaction to motivation?

\section{Method}

The method used to accomplish this research purpose is survey with causal technique. The reason to choose survey method as it explains or describes the phenomenon being studied concerning several affecting variables in a path diagram. Therefore, the technique used is path analysis.

There are for variables being stuied in this research namely variable $\mathrm{X} 1$ (job satisfaction), variable X2 (organizational commitment), variable X3 (job motivation), and variable Y (performance of Expert Member) as the main endogen variable.

Population in this research is all Procurement Experts of the House of Representatives, from 11 commissions and 5 Boards with total number of 117 board procurement experts of the Indonesian House Representatives (DPR RI). The research to determine number of representative research sample uses Taro

\footnotetext{
${ }^{1}$ John Barley, et al., Managing Organization Behavior (Australia : Jacaranda Wiley, Ltd, 1991) p. 116
} 
Yamane formulation that is aimed to obtain generalization validity over the research population. Therefore number of research sample is 91 procurement (AKD) experts. As the research population is homogeny, because averagely they have post graduate education background and have equal status namely as contract manpower with equal amount of income. This research uses "simple random sampling" as the sampling technique for 91 Procurement Experts (AKD).

\section{Figure of Theoritical Model Between Research Variable}

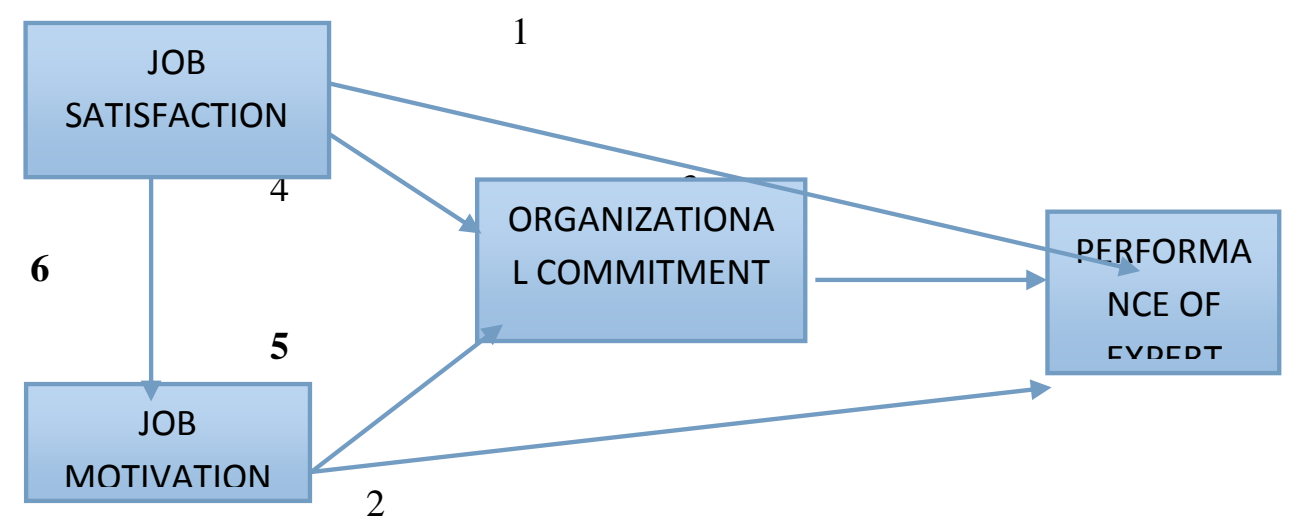

Based on the background, the issue formulation, the purpose of research as well as the above description, the hypothesis of this research is: Job satisfaction has direct positive effect to the performance of board procurement expert of the Indonesian House Representatives (DPR RI), Job motivation has direct positive effect to the performance of board procurement expert of the Indonesian House Representatives (DPR RI), Organizational commitment has direct positive effect to the performance of board procurement expert of the Indonesian House Representatives (DPR RI). Job satisfaction has direct positive effect to organizational commitment. Job motivation has direct positive effect to organizational commitment. Job satisfaction has direct positive effect to motivation.

\section{DISCUSSION AND RESULT}

Based on causal structural model to the part of model testing, and based on the hypothesis submitted, it can be described :

\section{Model of Structural Relation with Path Coefficient and Correlation Coefficient Between Variables}

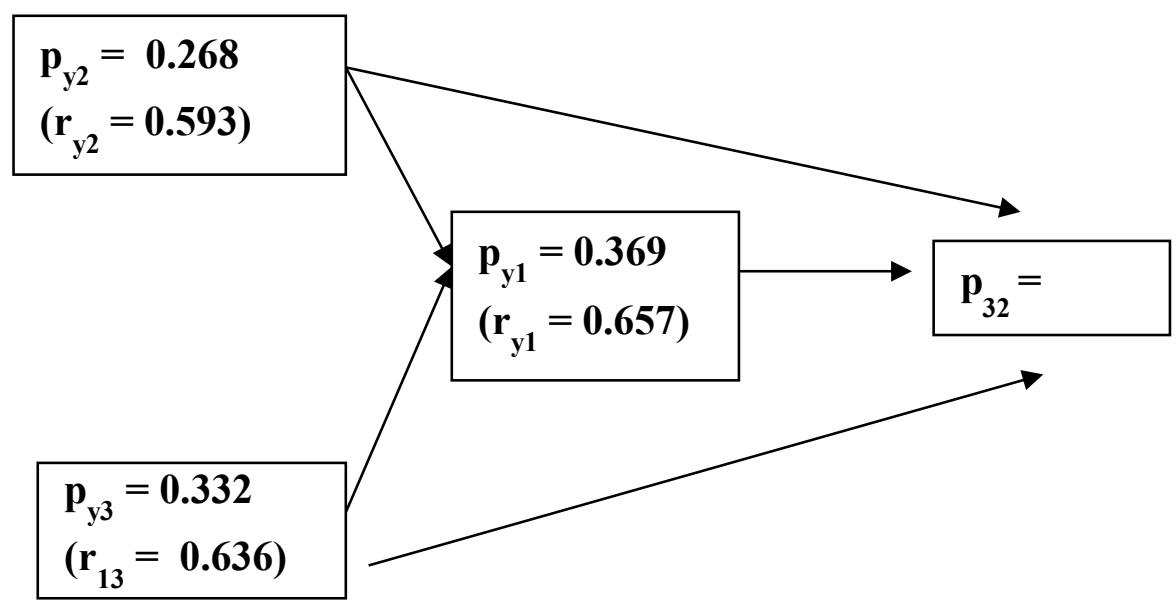

Direct Effect of Job Motivation (X1) to Work (Y) 
Based on the path value calculation result, it is obtained path coefficient $\mathrm{p}_{\mathrm{y} 1}=0.3690>0$, with value of $t_{\text {hitung }}$ of 4.582 which is larger than value of $t_{\text {tabel }}$ uses significance 0.01 of 2.633 (4.582 $>2.633$ ), therefore $\mathrm{H}_{0}$ is rejected, which means that job satisfaction has direct positive effect to performance. The hypothesis testing resulf shoes that job satisfaction has direct positive effect to the performance of board procurement expert. This is seen from the path coefficient obtained, the pyi is very significant at $\alpha$ level $=0.01$. Therefore it is tested through this research that job satisfaction has direct positive effect the performance of board procurement expert of the Indonesian House Representatives (DPR RI).

This is in accordance with Spector's opinion that job satisfaction lead to job performance) Other opinions such as Amstrong believes that increase of job satisfaction will produce work improvement. Several aspects of job satisfaction needed to be improved by the board procurement expert of the Indonesian House Representatives (DPR RI) to be used as facility and method to improve their performances are: a) Increase of facility support in the form of decent workspace facility, and provision of office tools such as computer, internet and other supporting equipment. b) Salary increase and adjustment of the expertise owned by board procurement expert of the Indonesian House Representatives (DPR RI) according to education levels and expertise. c) Development facility and provision of facility and learning opportunity in the form of course, education to improve their abilities.

\section{Direct effect of Motivation $\left(\mathrm{X}_{2}\right)$ to Performance (Y)}

Based on the path value calculation result, it is obtained path coefficient $\mathrm{p}_{\mathrm{y} 2}=0,268>0$, with value of $t_{\text {hitung }} 3.394$ which is larger from value of $t_{\text {tabel }}$ using 0.01 significancy of 2.633 (3.394 > 2.633), therefore $\mathrm{H}_{0}$ is rejected which means that motivation has direct positive effect to performance. The result of hypothesis testing that motivation has direct positive effect to performance. This is seen from the very significant path coefficient value at $\alpha$ level $=0.01$. Therefore it is tested through this research that motivation has a direct positive effect to performance of board procurement expert of the Indonesian House Representatives (DPR RI).

Several motivation aspects necessary to be increased in order to improve the performance of board procurement expert are: a) Worker's individual traits, among other things include interest of each individual, attitude, or different expectation of each individual. b) Traits of work, among other things include duties must be implemented, responsibility carried and satisfaction appears. c) Work environment and work situation of employee. Interaction pattern between employees highly affects his/her activity in working. She/he can be motivated by work partner. Rewards from the superior and organizational benefits determine a person's motivation to work.

\section{Direct Effect of organizational commitment $\left(\mathrm{X}_{3}\right)$ to Performance $(Y)$}

Based on the path value calculation result, it is obtained path coefficient $\mathrm{p}_{\mathrm{y} 3}=0.332>0$, with $\mathrm{t}_{\text {hitung }}$ value of 4.139 which is larger than $\mathrm{t}_{\text {tabel }}$ value using 0.01 significance of 2.633 (4.139>2.633), therefore $\mathrm{H}_{0}$ is rejected which means that organizational commitment has direct positive effect to performance. The result of hypothesis testing shows that organizational commitment has direct positive effect to performance. This is seen from the very significant path coefficient value at $\alpha$ level $=$ 0.01. Therefore, it is tested through this research that organizational commitment has direct positive effect to performance of board procurement expert of the Indonesian House Representatives (DPR RI).

This is pursuant to the expression of Watson and Tharp that "Commitment is not something you have, it is something you do". It means commitment is not something has already owned, but something must be done (achieved) so that it needs to be careful in giving limitation on commitment. Clifford states 
that organizational commitment is related to identification. For example, a person's commitment to organization is an affective response (attitude) generated from evaluation of work situation that relates or attaches individual to organization. Darwish A defines Organizational Commitment as an employee's obligation feeling to stay in an organization. This feeling is generated from normative internalization pressure that is given to an individual.

\section{Direct Effect of Job Satisfaction $\left(X_{1}\right)$ tto organizational commitment $\left(X_{3}\right)$}

Based on the path value calculation result, it is obtained path coefficient after being modified, namely $\mathrm{p}_{31}=0.353>0$, with $\mathrm{t}_{\text {hitung }}$ value of 3.521 which is larger than $\mathrm{t}_{\text {tabel }}$ value using 0.01 significance of $2.633(3.521>2.633)$, therefore $\mathrm{H}_{0}$ is rejected which means that job satisfaction has direct effect to organizational commitment. Naderi (2012) states that the current study supports significant positive correlation betwewn job satisfaction and organizational commitment. A logical explanation of this result is that organizational commitment is a function of job satisfaction. Various job satisfactions such as salary, work partner, supervision, and work alone are needed by workers to fulfill their basic needs.

Based on the analysis of several developed concepts, it can be synthesized that organizational commitment has feeling attachment to organizational aspects with indicators (a) Loyalty to organization, (b.) Acceptance of organizational purpose, (c). Implementation of organizational values, (d). Compliance to organizational regulation, and (e). Responsibility to organization.

\section{Direct Effect of Motivation (X2) to Commitment (X3)}

Based on the path value calculation result, it is obtained path coefficient after being modified, namely $\mathrm{p}_{32}=0.294$ with $t_{\text {hitung }}$ value of ..... which is larger than $t_{\text {tabel }}$ value using 0.01 significance of 2.633 (3.521. > 2.633), therefore $\mathrm{H}_{0}$ is rejected, which means that motivation has direct positive effect to organizational commitment.

In regard to job satisfaction has direct positive effect to organizational commitment, the testing shows that there is direct positive effice of job satisfaction to organizational commitment. High job satisfaction, may lead an increase of organizational commitment. The hypothesis testing result shows that motivation has direct effect to organizational commitment. This is seen from the very significant path coefficient value at $\alpha$ level $=0.01$. Therefore, it is tested through this research that motivation has direct positive effect to the performance of board procurement expert of the Indonesian House Representatives (DPR RI).

\section{Direct Effect of Job Satisfaction $\left(\mathbf{X}_{1}\right)$ to Motivation $\left(\mathbf{X}_{2}\right)$}

Based on the path value calculation result, it is obtained path coefficient after being modified, namely $\mathrm{p}_{21}=0.467>0$. with $\mathrm{t}_{\text {hitung }}$ value of 4.977 which is larger than $\mathrm{t}_{\text {tabel }}$ value using 0.01 significance of $2.633(4.977>2.633)$, therefore $\mathrm{H}_{0}$ is rejected, which means that job satisfaction has direct effect to job motivation. According to Hasibuan, motivation is a driver power that creates a person's work passion so that they are willing to cooperate, to work effectively and integrated with all of the efforts to achieve satisfaction. Meanwhile, Akitson and Hilgard which was quoted by Hariandja states that motivation is defined as factors that lead and encourage personal behavior or desire to conduct an activity as expressed in strong or weak efforts. it can be conveyed several recommendations in improving the expert's performance, as follows:

1. In increasing job satisfaction of all of these board procurement experts, it is recommended to the general secretary of the Indonesian House Representatives (DPR RI) division of Expert management in collaboration with BURT Agency of DPR RI, thus it must take into account of the expert's job satisfaction itself by motivation provision that considers each factor that is 
adjusted to the existing context. Increase of job satisfaction has direct positive effect to performance of the board procurement experts of the Indonesian House Representatives (DPR RI), this means that increase of job satisfaction will lead to increase of performance of the board procurement experts of the Indonesian House Representatives (DPR RI). By giving attention to the aspects of job satisfaction as follows a, provision of work facility, b. Work convenience, c. salary and reward for experts who are good and have good performance, d, job allowance and provision of periodic reward.

2. Making of job desk for experts to increase job satisfaction efficiency and effectiveness to lead to the increase of expert's performance so that the experts perceive clear responsibility to rise good motivation as follows a. To accept organization purpose, b To believe in organization values, c. To get involve in organizational duties, d. Loyalti to organization, e. Organizational responsibility that is reflected in measurement result in the form of score obtained from respondent's answers of a set of questionnaire, so thereafter General Secretary of DPR RI is able to rise good work motivation and work commitment of the board procurement experts of the Indonesian House Representatives (DPR RI).

3. It is recommended to General Secretary of board procurement experts of the Indonesian House Representatives (DPR RI) of Expert management division, especially board procurement expert to be involved in formal and informal of internal activity of the secretary, such as involve these experts in workshop, course, training and education in improving their abilities and performance, as well as to involve the board procurement expert (AKD) in non-formal activities within the environment of general secretary of the Indonesian House Representatives (DPR RI), such as family recreation, family outbond to create atmosphere of intimacy and harmony between staff and the board procurement experts (AKD). Certainly, this will improve their performance, satisfaction, motivation and commitment as part of the team that mutually support.

4. It is recommended to the General Secretary of the Indonesian House Representatives (DPR RI) and BURT that accommodate the board procurement experts in order to carry out evaluation and supervision over the performance of these experts, to clearly acknowledge their output in providing work contribution both in team in the commission and in bodies in DPR RI. This certainly will rise moral responsibility of the experts upon rights and obligation that they obtained during the office. Regular meeting and work review will make the procurement experts feel to be cared ad involved in daily activities, which is able to create high commitment to their performance.

\section{CONCLUSION}

Based on the data analysis described in the previous chapter, this research resulted findings and conclusions as follows:

1. Job satisfaction has a direct positive effect to performance, this means that improvement of work satisfaction will lead to improvement of the performance of board procurement experts of the Indonesian House Representatives (DPR RI). Work motivation has a direct positive effect to performance, this means that improvement of motivation will also lead to improvement of the performance of board procurement expert of the Indonesian House Representatives (DPR RI). Organization commitment has a direct positive effect to performance, this means that improvement of commitment will also lead to improvement of the performance of board procurement expert of the Indonesian House Representatives (DPR RI). Job satisfaction has a direct positive effect to improvement of organizational commitment and this will lead increase of job satisfaction of the board procurement experts of the Indonesian House Representatives (DPR RI). 
Motivation has direct positive effect to improvement of organizational commitment and this will lead to increase of motication, which will also lead to increase of commitment of board procurement experts of the Indonesian House Representatives (DPR RI). Motivation has positive direct effect to increase of job satisfaction and in this matter the increase of motivation will lead to the increase of job satisfaction of the board procurement experts of the Indonesian House Representatives (DPR RI).

\section{References}

David L. Watson and Roland G. Tharp, Self-Directed Behavior: Self-Modification for Personal Ajustment, $4^{\text {th }}$ Edition, (California: Books/Cole Publishing Company, 1995)

Dessler, Gary, "Manajemen Sumber Daya Manusia",( Jakarta : PT Prenhalindo, 2002)

Fred Luthans, Organizational Behavior, Seventh Edition. (Singapore: McGraw-Hill Book. Co, 1995)

James J. Mapes, Quantum Leap Thinking, Penterjemah, Basuki Hei Winarno, (Surabaya: Ikon Teralitera, 2003)

Jason A. ColQuitt, Jeffery A. Lepine dan Michael J. Wesson, Organizational Behavior (New York: Mc. Graw-Hill Companies, Inc., 2009)

John m. Ivancevich, Robert Konopakse dan Michael T. Matteson, Organizatioal Behavior and Management, Eight Edition, (New York: McGraw-Hill Companies, Inc., 2008)

Neil Anderson, Deniz S. Ones, Handan Kepir Sinangil, Chockkaligam Viswesvaran, Handbook of Industrial, Work and Organnizational Psychology, (London: Sage Publication Ltd., 2001)

Prof.Dr. Sudarwan Danim., Motivasi Kepemimpinan dan Efektivitas Kelompok, (PT. Rineka Cipta, Jakarta: 2004)

Lussier, Robert N, Achua Christopher F., Leadership:Theory, Application,Skill Development, (USA,South-Western College Publishing, 2001)

Robbins, Stephen P. Perilaka Organisasi. Terjemahan Molan Benyamin, (Jakarta: PT Indeks Kelompok Gramedia, 2006)

Yousef A. Darwish. Organizational Commitment and job satisfaction as predictors of attitudes toward organizational change in a non-western setting, (Personnel Review, Vol 29 Iss: 5, 2000)

Wibowo, Manajemen Kinerja, (Jakarta: PT. Raja Grafindo Persada, 2014 